\title{
Epigean fauna in no-till systems, pasture, eucalyptus and native savanna in Uruçuí, Piauí, Brazil
}

\author{
Adriano Veniciús Santana Gualberto ${ }^{1 *} \odot$, João Rodrigues da Cunha ${ }^{1} \oplus$, Renato Falconeres Vogado ${ }^{\oplus}$, \\ Luiz Fernando Carvalho Leite ${ }^{3} \odot$, Luis Alfredo Pinheiro Leal Nunes ${ }^{1} \odot$, Henrique Antunes de Souza ${ }^{3}{ }^{\circ}$

\footnotetext{
${ }^{1}$ Universidade Federal do Piauí, Teresina, PI, Brasil. E-mail: a.vsg@hotmail.com; joaorcsolos@hotmail.com; luisalfredo@ufpi.edu.br

${ }^{2}$ Universidade Federal da Paraíba, Areia, PB, Brasil. E-mail: renatoagro86@hotmail.com

${ }^{3}$ Embrapa Meio-Norte, Teresina, PI, Brasil. E-mail: luiz.f.leite@embrapa.br; henrique.souza@embrapa.br
}

ABSTRACT: The soil fauna is one of the bioindicators of soil quality that has greater sensitivity, being easily altered by changes that occur in natural and agricultural ecosystems. The objective of this work was to evaluate the density and diversity of the soil macrofauna and the functional groups of the epigeal macrofauna that are most representative in no-tillage, pasture, eucalyptus cultivation and native savanna systems in Uruçuí, Piauí, Brazil. Five soil management systems were used: pasture (PAS); no tillage soybean in corn straw (NT1); no tillage of corn under straw of mombaça grass (NT2); eucalyptus (EUC), in addition to a savanna area used as a reference (FA). Fauna collection was performed using pitfall traps containing $4 \%$ formaldehyde. The fauna was evaluated by the number of individuals per trap per day, wealth, average wealth, Shannon's diversity index and Pielou's uniformity index. The data was subjected to analysis of variance, and when significant, was subjected to the Friedman test. The pasture system had the least impact on edaphic fauna when compared to native savanna forest and when compared to management systems and the collembola, orthoptera and diptera groups were the most abundant in the studied management systems.

\section{Fauna epígea em sistemas de plantio direto, pastagem, eucalipto e cerrado nativo em Uruçuí, Piauí, Brasil}

RESUMO: A fauna do solo é um dos bioindicadores da qualidade do solo que possui maior sensibilidade, sendo facilmente alterada por mudanças que ocorrem nos ecossistemas naturais e agrícolas. $O$ trabalho teve como objetivo avaliar a densidade e diversidade da macrofauna do solo e os grupos funcionais da macrofauna epígea mais representativos em sistemas de plantio direto, pastagem, cultivo de eucalipto e Cerrado nativo em Uruçuí, Piauí, Brasil. Foram utilizados cinco sistemas de manejo do solo: (i) pastagem (PAS); (ii) plantio direto de soja sob palhada de milho (SPD1); (iii) plantio direto de milho sob palhada de capim mombaça (SPD2); (iv) eucalipto (EUC), além de (v) uma área de Cerrado usada como referência (MN). Foi realizada coleta da fauna, por meio de armadilhas do tipo pitfall contendo $4 \%$ de formol. A fauna foi avaliada pelo número de indivíduos por armadilha dia, riqueza, riqueza média, índice de diversidade de Shannon e índice de uniformidade de Pielou. Os dados foram submetidos à análise de variância, e quando significativo, foram submetidos ao teste de Friedman. Os grupos aranae, blattodea, scorpionidae e thisanura foram drasticamente afetados pelos sistemas de manejo utilizados em relação à condição natural. 0 sistema de pastagem foi o que apresentou menor impacto sobre a fauna edáfica quando comparado a mata nativa de cerrado.

Palavras-chave: rotação de cultura; diversidade; armadilhas pitfall; invertebrados do solo

\footnotetext{
*Adriano Veniciús Santana Gualberto - E-mail: a.vsg@hotmail.com (Corresponding author)

Associate Editor: Mario de Andrade Lira Júnior
} 


\section{Introduction}

Changes in the composition of tree species, through cultivation of a single species, affect the imbalance of edaphic communities since it reduces the number of ecological niches, favoring intra and interspecific competition, in addition to changes in abiotic factors such as temperature, humidity, light incidence (Baretta et al., 2014) and physical-chemical conditions of the soil (Oliveira Filho \& Baretta, 2016), thus the Brazilian savanna is considered one of the 34 biodiversity hotspots in the world (Mittermeier et al., 2011).

The invertebrate fauna is an important indicator of soil quality and performs important functions, such as fragmentation of organic residues, nutrient cycling, aeration, nutrient mobilization, and control of the trophic chain, such functions being vital for plant development and, consequently, for a balanced ecosystem (Araújo et al., 2017).

The soil invertebrate community can be conserved when the agricultural system provides a similar environmental structure to the original ecosystem. Thus, the edaphic fauna benefits from management systems that provide environmental conditions that favor the reproduction of invertebrates and a higher quality and quantity of plant residues, which serve as food and shelter (Nunes et al., 2019).

Management systems with pasture have proven efficient in the accumulation of organic residues in the soil, which can be justified due to its abundant root system that presents continuous renewal due to cutting and high rhizospheric effect, which favors the soil structure and the activity of soil biota, by providing food and better locomotion for edaphic organisms (Liáng et al., 2020).

Studies conducted by Santos et al. (2016), characterizing fauna in production systems in savanna areas in southwestern Piauí show that the no-till farming system provides greater abundance and richness of families compared to conventional soil preparation. In turn, Nunes et al. (2012) found that management systems adopted with different forages favored the presence of many individuals and species richness of edaphic fauna. In relation to the planted forest of eucalyptus, Cortez et al. (2015) observed that the large amount of burlap generated by the crop provides favorable environmental conditions for a greater diversity of soil fauna organisms.

Other studies have shown a pattern of increasing epigeal fauna as a function of successional advancement or preservation of the environment relative to anthropized areas (Brito et al., 2016; Vasconcelos et al., 2020). These authors concluded that the structural complexity of the vegetation, in terms of diversity, influenced greater deposition and better quality of the litter, providing more favorable conditions for food resources, shelter, and reproduction. Thus, any anthropic intervention can potentially affect the dynamics of the soil epigeal fauna and, consequently, the ecological functions in which it is involved.

In this sense, considering the importance of edaphic fauna biodiversity for soil quality and the constant changes in land use, this study aimed to evaluate the density and diversity of soil macrofauna and the functional groups of the most representative epigeal macrofauna in no-till, pasture, eucalyptus cultivation and native savanna systems in Uruçuí, Piauí, Brazil.

\section{Materials and Methods}

The work was carried out at Fazenda Nova Zelândia located in Uruçuí, PI, Brazil $\left(07^{\circ} 33^{\prime} 08^{\prime \prime} \mathrm{S}\right.$ and $\left.44^{\circ} 36^{\prime} 45^{\prime \prime} \mathrm{W}\right), 378 \mathrm{~m}$ above sea level. The climate according to Köppen and Geiger is $\mathrm{Aw}$, the average temperature is $27.2{ }^{\circ} \mathrm{C}$ and the average annual rainfall is $817.8 \mathrm{~mm}$ corresponding to the year 2017 (INMET, 2018) (Figure 1).

The soil is classified as Oxisol (Araújo et al., 2010), with chemical characterization of the areas according to Table 1.

Four management systems were used for the study: pasture (PAS), no-till soybean under corn stover (NT1), no-till corn under mombaça grass stover (NT2), eucalyptus (EUC), and a native savanna forest area (FA) as reference. The history of land use in the different management systems is presented in Table 2.

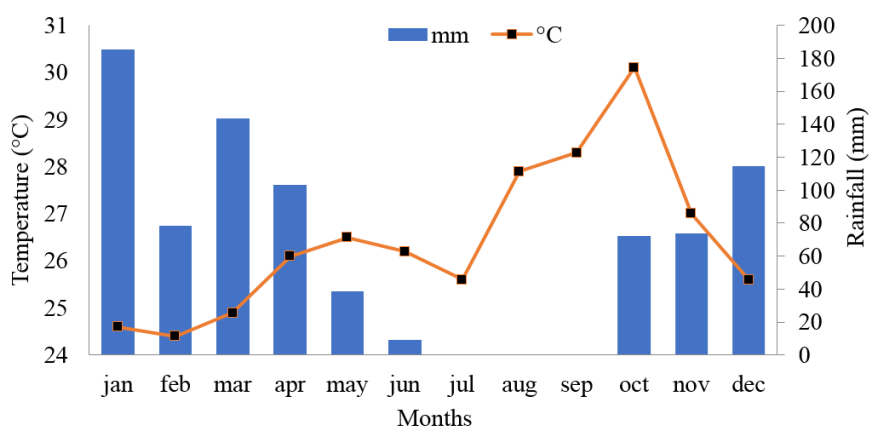

Figure 1. Rainfall and average monthly temperatures corresponding to the year 2017, Uruçuí, PI, Brazil (INMET, 2018).

Table 1. Chemical characterization and particle size in the 0-0.1 m layers of a Oxisol submitted to different management systems in Uruçuí, Piauí, Brazil.

\begin{tabular}{|c|c|c|c|c|c|c|c|c|c|c|}
\hline \multirow{2}{*}{ Systems } & \multirow{2}{*}{ pH } & $\mathbf{P}$ & K & $\mathrm{Ca}$ & Mg & Al & $\mathrm{H}+\mathrm{Al}$ & Sand & Silte & Clay \\
\hline & & \multicolumn{2}{|c|}{$\left(\mathrm{mg} \mathrm{dm}^{-3}\right)$} & \multicolumn{4}{|c|}{$\left(\mathrm{cmol}_{\mathrm{c}} \mathrm{dm}^{-3}\right)$} & \multicolumn{3}{|c|}{$\left(\mathrm{g} \mathrm{kg}^{-1}\right)$} \\
\hline PAS & 5.0 & 37.8 & 121.2 & 5.08 & 0.8 & 0.04 & 5.1 & 775 & 37 & 188 \\
\hline NT1 & 4.8 & 27.7 & 82.1 & 3.81 & 0.5 & 0.07 & 4.9 & 594 & 270 & 136 \\
\hline NT2 & 5.0 & 38.8 & 78.2 & 3.33 & 0.7 & 0.06 & 3.3 & 687 & 184 & 129 \\
\hline EUC & 4.7 & 58.2 & 50.8 & 2.79 & 0.9 & 0.11 & 5.2 & 518 & 326 & 156 \\
\hline FA & 3.8 & 2.5 & 35.2 & 0.65 & 0.3 & 1.30 & 8.3 & 639 & 218 & 143 \\
\hline
\end{tabular}

PAS: Pasture with mombaça grass for haymaking; NT1: No-till soybean system under corn stover; NT2: No-till corn system under mombaça grass stover (NT2); EUC: Eucalyptus; FA: Native savanna forest. 
Table 2. History of the management systems studied, in Uruçuí, Piauí, Brazil.

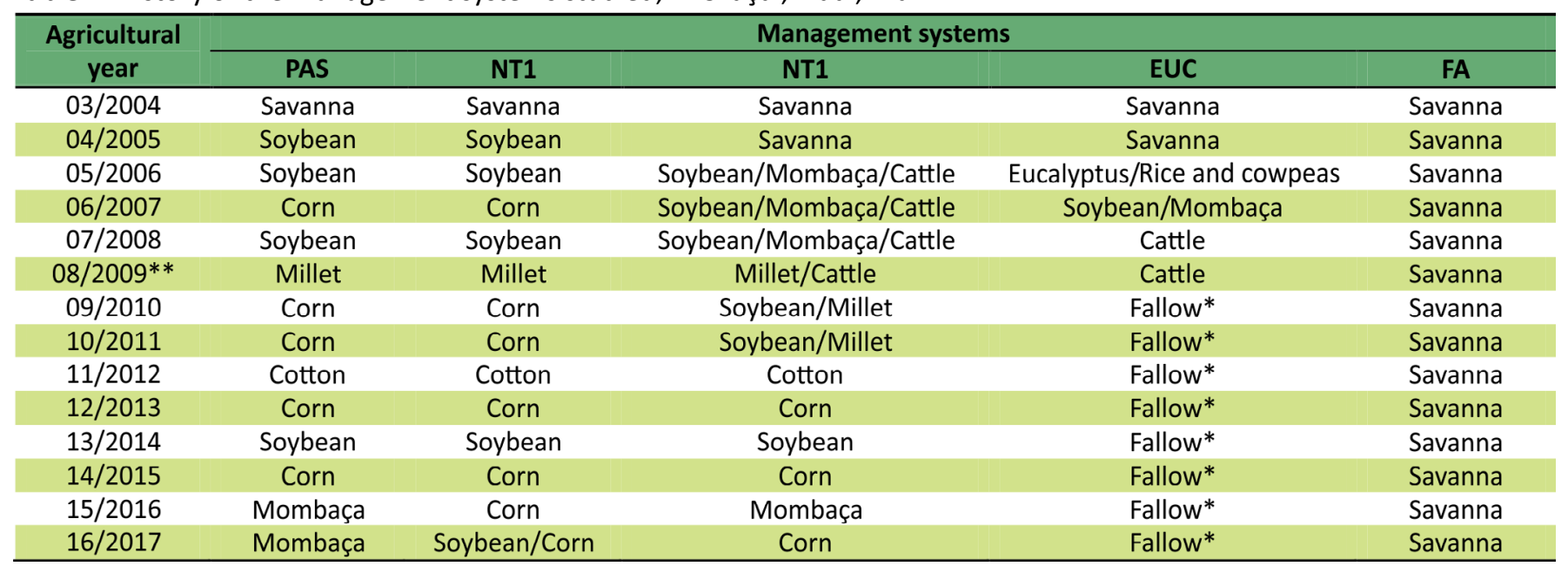

PAS: Pasture with mombaça grass for haymaking; NT1: No-till soybean system under corn stover; NT2: No-till corn/soybean system under mombaça grass stover; EUC: Eucalyptus; FA: Native savanna forest. Cattle: Cattle of mixed breed of Nelore and Gyr under stocking rate of 2.4 UA ha ${ }^{-1}$. AU: Animal Unit with $450 \mathrm{~kg}$. * Fallow from animal and agricultural crop inputs, with the presence of mombaça grass between the rows. ${ }^{* *}$ In the $09 / 08$ agricultural year, the areas referring to the evaluated systems were not cultivated, receiving only millet as a cover crop, and in NT2 there was the entrance of animals for grazing.

The management system with eucalyptus was installed in the 2005/2006 agricultural year, and liming was performed with $6 \mathrm{Mg} \mathrm{ha}^{-1}$ with incorporation of limestone in the area. All liming practices that had limestone incorporated into the soil were done at a depth of $0.22 \mathrm{~m}$ with the use of a 28 " plow.

The Eucalyptus urograndis clone " $\mathrm{h} 75$ " was planted with 3 different spacing in the rows, being $1.5 \times 1.5 \mathrm{~m}, 3 \times 1.5 \mathrm{~m}$ and $3 \times 2 \mathrm{~m}$ and with spacing of $14 \mathrm{~m}$ between rows, being rows of 3 and 5 rows of eucalyptus. Also in the 2005/2006 crop year early rice cv. Aimoré was grown with fertilization of $300 \mathrm{~kg}$ ha $^{-1}$ of the formulated 10-30-10, and in the same crop were planted cowpea cv. Nova Era and cv. Guariba.

In the following crop, soybean cv. BRS278 and BRS279 were planted with $350 \mathrm{~kg}$ of 5-20-20 fertilization. After the soybean harvest, mombaça grass was grown and grazed at a stocking rate of $2.4 \mathrm{UA} \mathrm{ha-1}$. The fertilization was made in a specific way, with $150 \mathrm{~kg} \mathrm{ha}^{-1}$ of the formulation 06-21-06, also containing $12 \% \mathrm{Ca}, 3 \% \mathrm{~S}, 0.3 \% \mathrm{Zn}$ in foundation in January 2006 and $200 \mathrm{~kg} \mathrm{ha}^{-1}$ of the formulation 20-01-20, in cover in March/2006, January/2007 and January/2008.

Fertilizer management in the other areas studied was done according to need, based on soil analysis and the recommendations of Sousa and Lobato (2004), where all areas in the first year of cultivation received liming of $6 \mathrm{Mg}$ ha $^{-1}$ and incorporated as previously reported.

We also applied $1 \mathrm{t} \mathrm{ha}^{-1}$ of agricultural gypsum on surface in all areas in the 2014/2015 crop year, and $160 \mathrm{~kg} \mathrm{ha}^{-1}$ of mono-ammonium phosphate (MAP), $120 \mathrm{~kg} \mathrm{ha}^{-1}$ of potassium chloride (KCl), $250 \mathrm{~kg} \mathrm{ha}^{-1}$ of ammonium sulfate (S. A.) and 230 $\mathrm{kg} \mathrm{ha}^{-1}$ of urea were also made available in the whole area with the exception of the eucalyptus system.

The last liming performed was in the 2011/2012 crop year, with $2.5 \mathrm{t} \mathrm{ha}^{-1}$ dolomitic limestone applied to the PAS, NT1 and NT2 areas and incorporated as mentioned. In the 2015/2016 and 2016/2017 agricultural years, $170 \mathrm{~kg} \mathrm{ha}^{-1}$ of Lithotamnium was applied, a product derived from calcareous marine algae, which in addition to $\mathrm{Ca}$ and $\mathrm{Mg}$ has variable contents of $\mathrm{P}$, $\mathrm{K}$, and micronutrients, with the exception of the PAS and eucalyptus systems.

In the agricultural years 2005/2006, 2006/2007, and 2007/2008 in the NT2 area, after the soybean harvest, mombaça grass was grown as ground cover, and grazed under an animal density of 2.4 UA ha-1. Also in NT2 in the 2009/2010 and 2010/2011 crop years corn was used as a cover crop after the soybean harvest.

In the PAS system, the removal of mombaça grass for hay occurred only in the 2015/2016 crop year, and in 2016/2017 the area was fallow with respect to the input of animals and/or machinery (Table 2). The genetic material used in the planting of NT2 was Supreme Viptera corn (SX7331) and in the planting of NT1 was FTS Graciosa RR soybean.

The collection of epigeal fauna was conducted at the end of the rainy season in April 2017, close to the soybean harvest. The organisms were captured using pitfall traps, according to the methodology described by Moldenke (1994). These traps were made of plastic containers $10 \mathrm{~cm}$ high and $10 \mathrm{~cm}$ in diameter with a cover, which were buried in the ground with the edge at surface level. The cover of the trap was made with plastic plates with a wooden tripod in order to reduce the entry of water from rainfall and plant remains from the crop.

Seven traps per management system were set up in transects with a distance of $10 \mathrm{~m}$ between each trap. In each trap, $200 \mathrm{~mL}$ of a $4 \%$ concentration formaldehyde preservative solution was added to prevent deterioration of the insects. After seven days of installation in the field, the traps were removed from the ground and the individuals collected identified and classified according to order or class level.

The edaphic fauna was evaluated by the number of individuals per trap per day, fauna richness, which corresponds to the number of groups identified, and average richness, which represents the average number of individuals per trap. 
The total number of taxonomic groups present was evaluated by the Shannon diversity index and Pielou uniformity index, calculated by the Equations 1 and 2:

$$
\begin{gathered}
\mathrm{H}=-\sum \mathrm{pi} \times \ln (\mathrm{pi}) \\
\mathrm{E}=\frac{\mathrm{H}}{\ln (\mathrm{S})}
\end{gathered}
$$

where:

$$
\begin{array}{ll}
\mathrm{H} & \text { - Shannon diversity index; } \\
\mathrm{pi} & \text { - proportion of the individuals that belong to the ith } \\
\mathrm{mily} ; & \\
\mathrm{E} & \text { - Pielou uniformity index: } \\
\text { In } & \text { - logarithm in base neperian; } \\
\mathrm{S} & \text { - number of species or groups (Begon et al., 1996). }
\end{array}
$$
family;

Data regarding the number of individuals per trap per day (ind. arm $^{-1}$ day $^{-1}$ ) and average richness was submitted to analysis of variance with the help of the statistical program R ( $R$ Core Team, 2020). The Shapiro-Wilk and Levene tests were performed to verify the normality and homogeneity of variance of the data, and then submitted to non-parametric analysis, using Friedman test, at $5 \%$ probability. A multivariate principal component analysis (PCA) was also performed between the taxonomic groups and the management systems, using the same statistical program.

\section{Results and Discussion}

There are 22 faunal groups present in the different management systems studied (Table 3 ). There were changes in the soil fauna variables evaluated as a function of the soil management system, corroborating other works in the savanna piauiense (Santos et al., 2016; Araújo et al., 2017).

The lowest number of individuals collected per trap day $^{-1}$ was recorded in the native savanna forest (FA), while the no-till farming system 1 (NT1) showed the highest values, differing from the others (Table 3). However, the high standard error observed in this system, reveals a large spatial heterogeneity, and shows that certain groups of invertebrates in were only found in a few traps.

As for total richness, the highest value was observed in the PAS area followed by FA (Table 3). In general, the more diverse the vegetation, the greater the heterogeneity of organic residues, which results in a higher diversity of the fauna community (Oliveira et al., 2019). However, the annual input of organic inputs (crop residues and herbaceous biomass) in the management system with pasture is $10 \mathrm{Mg} \mathrm{ha}^{-1}$ (Bernardes et al., 2010), a factor that creates an optimal environment for food supply and better locomotion of organisms, favoring the accumulation of organisms in this system.

According to Wall et al. (2020), the production of grass mulch enables a large root deposition in various stages of decomposition, due to the constant cycling of fine roots that are mostly concentrated in the surface layer, and thus contribute as food for epigeal fauna, favoring their multiplication. In turn, areas of native vegetation have a continuous input of a diverse range of easily decomposable organic material, which allows colonization by different organisms (Vasconcelos et al., 2020).

In relation to Shannon's diversity index and Pielou's uniformity index, PAS, FA, and NT2 presented higher values in relation to the other systems evaluated (Table 3 ), which indicates that there was a greater diversity and number of dominant groups in these systems. On the other hand, the lowest values of these variables were observed in the NT1 and EUC systems. This can be attributed to the predominance of the Collembola, Orthoptera and Diptera groups in NT2 and the Collembola and Diptera groups in EUC, which accounted for about $80 \%$ of the total individuals collected in these areas (Table 4), thus contributing to lower diversity and uniformity.

The use of the no-till farming system, which involves maintaining stubble in the soil, has been practiced in an attempt to increase the organic matter content and improve soil quality after the annual crop harvest (Torres et al., 2015), which would supposedly favor the presence of edaphic fauna individuals. However, the history of NT1 shows that over the years there was a predominance of Soy/Corn succession. On the other hand, in NT2 the management also involved Mombasa grass that resulted in a higher phytomass production (Table 1 ). For Alves et al. (2020) the ideal for no-till would be the use of intercropping between grasses and legumes, since the former contribute with relatively high amounts of phytomass, characterized by a high $\mathrm{C}: \mathrm{N}$ ratio, which would counterbalance a plant material whose decomposition is relatively fast generated by legumes, and thus increase the persistence of soil cover, favoring a greater diversity of soil invertebrates.

Among the groups with the highest expression (Table 4) are Collembola, Orthoptera, and Diptera, representing

Table 3. Number of individuals, total richness, mean richness, Shannon diversity index and Pielou's equitability index in different management systems in Uruçuí, Piauí, Brazil.

\begin{tabular}{cccccc}
\hline $\begin{array}{c}\text { Management } \\
\text { systems }\end{array}$ & Ind.Arm.day ${ }^{-1} \pm$ Standard error & $\begin{array}{c}\text { Total } \\
\text { wealth }\end{array}$ & $\begin{array}{c}\text { Average } \\
\text { wealth }\end{array}$ & Shannon \\
\hline PAS & $50.55 \pm 1.9 \mathrm{~b}$ & 18 & $11 \mathrm{a}$ & 2.73 \\
NT & $91.37 \pm 13.0 \mathrm{a}$ & 13 & $8 \mathrm{a}$ & 2.00 \\
NT2 & $38.12 \pm 3.9 \mathrm{bc}$ & 12 & $8 \mathrm{a}$ & 2.71 & 0.55 \\
EUC & $42.85 \pm 5.5 \mathrm{~b}$ & 11 & $9 \mathrm{a}$ & 2.08 \\
FA & $14.49 \pm 2.4 \mathrm{c}$ & 16 & $9 \mathrm{a}$ & 2.65 \\
\hline
\end{tabular}

NT1: No-till system of soybean under corn stover; NT2: No-till system of corn/soybean under mombaça grass stover; EUC: Eucalyptus; FA: Native savanna forest. Averages followed by the same letter in the column do not differ statistically by Friedman test $(p \geq 0.05)$. Ind. arm. day ${ }^{-1}$ : Individuals per trap per day. 
Table 4. Relative distribution (\%) of epigeal fauna in different management systems in Uruçuí, Piauí, Brazil.

\begin{tabular}{|c|c|c|c|c|c|c|c|}
\hline \multirow{3}{*}{ Groups } & \multirow{3}{*}{$\begin{array}{c}\text { Taxonomic } \\
\text { Level }\end{array}$} & \multicolumn{6}{|c|}{ Management systems ${ }^{1}$} \\
\hline & & PAS & NT1 & NT2 & EUC & FA & Total \\
\hline & & \multicolumn{6}{|c|}{ (\%) } \\
\hline Acari & Order & 0.6 & - & - & - & - & 0.15 \\
\hline Araneae & Order & 1.4 & 0.9 & 0.5 & 2.9 & 10.1 & 1.73 \\
\hline Blattodea & Order & 0.1 & - & - & - & 2.3 & 0.18 \\
\hline Isoptera & Suborder & 0.6 & 0.3 & 0.3 & 0.3 & 1.0 & 0.40 \\
\hline Collembola & Suborder & 12.4 & 4.1 & 60.3 & 50.2 & 39.8 & 35.90 \\
\hline Chilopoda & Order & 0.9 & 3.0 & - & 1.0 & - & 0.92 \\
\hline Coleoptera & Order & 5.7 & 3.5 & 1.8 & 1.2 & 4.7 & 3.13 \\
\hline Dermaptera & Order & 1.7 & 0.4 & 1.2 & 1.3 & 0.4 & 1.13 \\
\hline Diptera & Order & 19.8 & 18.2 & 12.9 & 28.8 & 12.0 & 17.55 \\
\hline Formicidae & Order & 11.1 & 26.1 & 5.7 & 8.5 & 22.0 & 12.26 \\
\hline Hemiptera & Order & 1.9 & 4.5 & 1.1 & 2.8 & - & 2.08 \\
\hline Auchenorryncha & Suborder & - & - & - & - & 0.6 & 0.04 \\
\hline Heteroptera & Suborder & 0.2 & - & 0.4 & - & 0.3 & 0.24 \\
\hline Hymenoptera & Order & 5.6 & 9.2 & 2.0 & 2.0 & 0.3 & 4.08 \\
\hline Lepidoptera & Order & 0.4 & - & - & - & - & 0.10 \\
\hline Orthoptera & Order & 37.2 & 28.3 & 13.5 & 0.3 & 0.1 & 19.16 \\
\hline Plecoptera & Order & - & - & 0.1 & - & - & 0.05 \\
\hline Pseudoscorpionide & Order & - & - & - & - & 3.0 & 0.19 \\
\hline Protura & Order & - & - & - & - & 1.1 & 0.07 \\
\hline Scorpionide & Order & 0.1 & - & - & - & - & 0.02 \\
\hline Tricoptera & Order & 0.1 & - & - & - & - & 0.03 \\
\hline Thisanura & Order & 0.1 & 1.4 & 0.2 & 0.7 & 2.4 & 0.60 \\
\hline
\end{tabular}

${ }^{1}$ Management systems: NT1: No-till system of soybean under corn stover; NT2: No-till system of corn/soybean under mombaça grass stover; EUC: Eucalyptus; FA: Native savanna forest.

percentages of $35.9,19.2$, and $17.5 \%$, respectively, adding up to a total of more than $70 \%$ of the individuals found in the areas.

The collembola group represented $60 \%$ of the individuals in NT1, $50 \%$ in EUC and $40 \%$ in FA, this dominance presented by the collembola group in the burlap is well documented (Menta et al., 2014; Innangi et al., 2018). However, the frequency of these individuals is positive, as these soil microarthropods have significant influence on soil microbial ecology, nutrient cycling, and soil fertility by feeding on soil microorganisms and dead organic matter (Oliveira Filho \& Baretta, 2016).

The groups Araneae and Pseudoscorpionida showed higher occurrence in the native savanna area. Similar result on the density of the Araneae group was observed by Araújo et al. (2017), working in preserved and unpreserved native savanna area. The predominance of the Araneae group in FA may be associated with the accumulation of leaves in the reference area, as this greater amount of leaves provides greater heterogeneity in the burlap microhabitat. Research by Freiberg et al. (2020) showed that in an annual crop-livestock integration system, grazing intensification can negatively influence the abundance and richness of terrestrial spiders.

The amount of litter in the area in natural equilibrium creates thermally more comfortable environments for spiders, mainly by preventing water loss, since water loss is one of the main ecological problems of arthropods, especially spiders (Varjão et al., 2010). Also according to the authors, the spaces between the leaves, the basal side of the leaves and the openings between them create foraging sites for the spiders and protect them from the light intensity that usually affects their behavior, forcing them to inhabit new areas.

Some groups showed low density, but are important in maintaining the balance of the soil and the food chain, such as: Blattodea, Dermaptera, Hemiptera, Isoptera and Chilopoda and in general they predominated in almost all systems, except for the Blatodea group, which only predominated in FA. The Dermaptera, Chilopodae, and Hemiptera groups are predators, while the Blattodea group is saprophagous and is part of the diet of many mammals, birds, and reptiles (Correia \& Oliveira, 2005).

The Isoptera group acts in the decomposition process of organic matter and mainly assimilate cellulose decomposition products such as hemicellulose, starch, and sugars (Brito et al., 2016). According to the authors, these organisms have a number of gastrointestinal symbionts that enable this group to solve the issue of the high $\mathrm{C} / \mathrm{N}$ ratio of their trophic resource, facilitating the cycling of nutrients performed by fungi and bacteria. This group represented only $0.4 \%$ of the individuals observed, corroborating the results observed by Santos et al. (2008) in savanna areas.

The study of the relationship between the distribution of individuals of each taxonomic group and the soil management systems was performed by means of an ordination generated by principal components, involving the epigean fauna 
community and the management systems, the variability retained in principal components 1 and 2 explained $79.92 \%$ of the original variability, where CP1 and CP2 each retain 52.87 and $22.04 \%$, respectively, of the original data information (Figure 2).

The PAS area showed the greatest relationship with the Orthoptera, Coleoptera, Dermaptera, Isoptera, Lepdoptera, Tricoptera, Acari, and Scorpionida groups, showing the greatest influence on CP 1 (Figure 2). The prevalence of these specific groups may be associated with the initial changes that occur with the conversion of savanna vegetation to pasture (e.g., cutting, burning, and topsoil transport), which totally or partially compromise the soil fauna, with colonization again only by groups that accept the new resources (Benito et al., 2004).

PAS show less impact on soil fauna when they are introduced in savanna-type vegetation and when compared to more intensive management systems (Pompermaier et al., 2020), corroborating with results found in this work. This was probably due to the absence of animals and/ or machinery for two years prior to collection as shown in Table 2. In addition, the annual input of organic inputs (crop residues and herbaceous biomass) in these systems is of the order of $10 \mathrm{Mg} \mathrm{ha}^{-1}$ (Bernardes et al., 2010).

The presence of several important groups of soil fauna, including formicity, coleoptera, orthoptera, and collembolla, occurred to the conservationist systems NT1, NT2, and PAS showing a similarity of soil management probably due to better soil chemical conditions and a good amount of organic matter in the surface layer (Figure 2). Furthermore, these management systems promoted a diversification of plant residues, increasing the quality of the leaf litter. This combination contributes to a better occurrence of soil fauna groups, as also observed by Baretta et al. (2014).

FA area negatively influenced CP 1 by associating with the groups Araneae, Blattodea, Pseudoscorponida, Protura

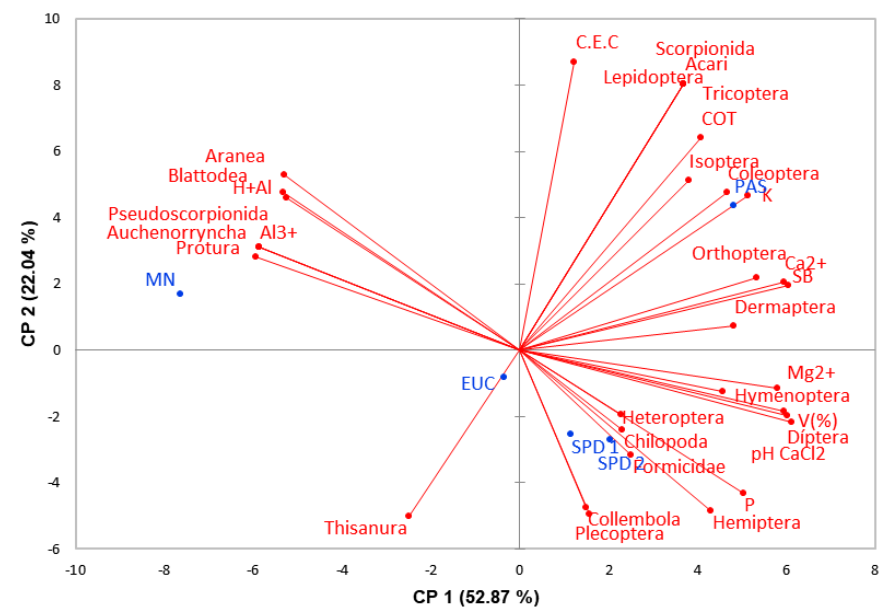

NT1: No-till system of soybean under corn stover; NT2: No-till system of corn/soybean under mombaça grass stover; EUC: Eucalyptus; FA: Native savanna forest.

Figure 2. Principal Component Analysis (PCA) between different management systems, soil fertility and the main taxonomic groups of the edaphic fauna in the savanna. and Auchenorryncha. Despite this environment presenting a greater variety of organic residues, the high concentration of $\mathrm{Al}^{3+}$ and potential acidity $(\mathrm{H}+\mathrm{Al})$ in the soil may have caused a lower diversity of fauna, compared to the other areas that were contemplated with soil fertility correction, favoring an increase in biological activity (Baretta et al., 2014).

In turn, the system with eucalyptus, despite generating an average plant litter around $14.1 \mathrm{Mg} \mathrm{ha}^{-1}$ (Gatto et al., 2014), showed no association with any group of edaphic fauna. Eucalyptus plant litter has materials with high $\mathrm{C} / \mathrm{N}$ ratio (> 25 ) and high levels of lignin and polyphenols, according to the part of the plant studied, and also high C/P and C/S ratio, which contributes to a slow decomposition of the residue (Gatto et al., 2014).

Low quality of the plant litter (i.e. high lignin content in $\mathrm{C} / \mathrm{N}$ ratio) restricts the activities of soil fauna (Makkonen et al., 2012; Sauvadet et al., 2017; Tan et al., 2020). These studies have shown that a high lignin concentration can reduce the decomposition rate of the plant litter, and a low initial lignin concentration can cause a high contribution to the density and diversity of the soil fauna.

\section{Conclusions}

The groups aranae, blattodea, scorpionidae and thisanura were drastically affected by the management system used compared to the natural condition.

The no-till system with corn/soybean rotation under mombaça grass straw favored the conservation of edaphic fauna diversity, compared to no-till soybean under corn straw.

The groups collembola, orthoptera and diptera were the most abundant in all management systems studied.

The systems of pasture, no-till soybean under corn stover, no-till with corn/soybean rotation under mombaça grass stover, and native forest favored the presence of various groups of edaphic fauna.

The pasture system had the least impact on edaphic fauna compared to the native forest.

\section{Compliance with Ethical Standards}

Author contributions: Conceptualization: AVSG, JRC, RFV; Formal analysis: AVSG, LFCL, LAPLN, HAS; Investigation: AVSG, JRC, RFV, LFCL, LAPLN, HAS; Methodology: AVSG, LFCL, LAPLN, HAS; Supervision: LFCL, LAPLN, HAS; Validation: HAS; Writing-Original Draf: HAS; Writing - review \& editing: AVSG, LAPLN, HAS.

Conflict of interest: The authors declare that they have no conflict of interest.

Financing source: Universidade Federal do Piauí (UFPI), Universidade Estadual do Piauí (UESPI), Empresa Brasileira de Pesquisa Agropecuária (EMBRAPA), Coordenação de Aperfeiçoamento de Pessoal de Nível Superior (CAPES) and Conselho Nacional de Desenvolvimento Científico e Tecnológico (CNPq). 


\section{Literature Cited}

Alves, L. A.; Denardin, L. G. de O.; Martins, A. P.; Bayer, C.; Veloso, M. G.; Bremm, C.; Carvalho, P. C. de F.; Machado, D. R.; Tiecher, T. The effect of crop rotation and sheep grazing management on plant production and soil $\mathrm{C}$ and $\mathrm{N}$ stocks in a long-term integrated croplivestock system in Southern Brazil. Soil and Tillage Research, v. 203, e104678, 2020. https://doi.org/10.1016/j.still.2020.104678.

Araújo, A. S. F.; Magalhaes, L. B.; Santos, V. M.; Nunes, L. A. P. L.; Dias, C. T. S. Propriedades biológicas de Cerrado sensu stricto preservado e não preservado do Nordeste do Brasil. Brazilian Journal of Biology, v. 77, n. 1, p. 16-21, 2017. https://doi.org/10.1590/15196984.06715

Araújo, F. S. .; Salviano, A. A. C. .; Leite, L. F. C. .; Souza, Z. M. de; Sousa, A. C. M. de. Physical quality of a yellow Latossol under integrated crop-livestock system. Revista Brasileira de Ciência do Solo, v. 34, n. 3, p. 717-723, 2010. https://doi.org/10.1590/S010006832010000300013.

Baretta, D.; Bartz, M. L. C.; Fachini, I.; Anselmi, R.; Zortéa, T.; Baretta, C. R. D. M. Soil fauna and its relation with environmental variables in soil management systems. Revista Ciência Agronômica, v. 45, n. 5, p. 871-879, 2014. https://doi.org/10.1590/S180666902014000500002.

Begon, M.; Haper, J. L.; Townsed, C. R. Ecology: individuals, populations and communities. 3.ed. Oxford: Blackwell Science, 1996. 1068p.

Benito, N. P.; Brossard, M.; Pasini, A.; Guimarães, M. D. F.; Bobillier, B. Transformations of soil macroinvertebrate populations after native vegetation conversion to pasture cultivation (Brazilian Cerrado). European Journal of Soil Biology, v. 40, n. 3-4, p. 147-154, 2004. https://doi.org/10.1016/j.ejsobi.2005.02.002.

Bernardes, T. G.; Silveira, P. M. da; Mesquita, M. A. M. H.; Aguiar, R. A. de; Mesquita, G. M. H. Decomposição da biomassa e liberação de nutrientes dos capins braquiária e mombaça em condiçõ es de Cerrado. Pesquisa Agropecuaria Tropical, v. 40, n. 3, p. 370-377, 2010. https://doi.org/10.5216/pat.v40i3.5584.

Brito, M. F. de; Tsujigushi, B. P.; Otsubo, A. A.; Silva, R. F. da; Mercante, E. F. M. Diversidade da fauna edáfica e epigeica de invertebrados em consórcio de mandioca com adubos verdes. Pesquisa Agropecuaria Brasileira, v. 51, n. 3, p. 253-260, 1 mar. 2016. https:// doi.org/10.1590/S0100-204X2016000300007.

Correia, M. E. F.; Oliveira, L. C. M. de. Importância da fauna de solo para a ciclagem de nutrientes. In: Aquino, A. M. de; Assis, R. L. de (Eds.). Processos biológicos no sistema solo-planta: ferramentas para uma agricultura sustentável. Brasília, DF: Embrapa Informação Tecnológica; Seropédica: Embrapa Agrobiologia, 2005. p.77-99.

Cortez, C. T.; Barbosa, L. R.; Morais, G. P. De; Nunes, L. A. P. L.; Araújo, A. S. F. De; Correia, M. E. F. Soil fauna under eucalypt stands of different ages in the Savanna of Piauí. Científica, v. 43, n. 3, p. 280-286, 2015. https://doi.org/10.15361/1984-5529.2015v43n3p280-286.

Freiberg, J.A.; Dambros, C. de S.; Rodrigues, E.N.L.; Teixeira, R.A.; Vieira, Â. D. H. N.; Almeida, H. S. de; Carvalho, P. C. de F.; Jacques, R. J. S. Increased grazing intensity in pastures reduces the abundance and richness of ground spiders in an integrated croplivestock system. Agronomy for Sustainable Development, v.40, article 1, 2020. https://doi.org/10.1007/s13593-019-0604-0.
Gatto, A.; Bussinguer, A. P.; Ribeiro, F. C.; Azevedo, G. B. de; Bueno, M. C.; Monteiro, M. M.; Souza, P. F. de. Ciclagem e balanço de nutrientes no sistema solo-planta em um plantio de eucalyptus sp., no Distrito Federal, Brazil. Revista Brasileira de Ciência do Solo, v. 38, n. 3, p. 879 887, 2014. https://doi.org/10.1590/S0100-06832014000300019

Innangi, M.; Menta, C.; Pinto, S.; Danise, T.; D’alessandro, F.; Fioretto, A. Integrating chemical, biological and soil fauna variables during beech leaf litter decay: A partial least squares approach for a comprehensive view of the decomposition process. Applied Soil Ecology, v. 130, p. 69-78, 2018. https://doi.org/10.1016/j.apsoil.2018.05.023.

Instituto Nacional de Metereologia - INMET. Clima. http://www.inmet. gov.br/sonabra/pg_dspDadosCodigo_sim.php?QTMONg. 18 Jan. 2018.

Liáng, L. L.; Kirschbaum, M. U. F.; Giltrap, D. L.; Wall, A. M.; Campbell, D. I. Modelling the effects of pasture renewal on the carbon balance of grazed pastures. Science of the Total Environment, v. 715, e136917, 2020. https://doi.org/10.1016/j.scitotenv.2020.136917.

Makkonen, M.; Berg, M. P.; Handa, I. T.; Hättenschwiler, S.; Ruijven, J. Van; Bodegom, P. M. Van; Aerts, R. Highly consistent effects of plant litter identity and functional traits on decomposition across a latitudinal gradient. Ecology Letters, v. 15, n. 9, p. 1033-1041, 2012. https://doi.org/10.1111/j.1461-0248.2012.01826.x.

Menta, C.; García-Montero, L. G.; Pinto, S.; Conti, F. D.; Baroni, G.; Maresi, $M$. Does the natural "microcosm" created by Tuber aestivum affect soil microarthropods? A new hypothesis based on Collembola in truffle culture. Applied Soil Ecology, v. 84, p. 31-37, 2014. https:// doi.org/10.1016/j.apsoil.2014.06.012.

Mittermeier, R. A.; Turner, W. R.; Larsen, F. W.; Brooks, T. M.; Gascon, C. Global biodiversity conservation: the critical role of hotspots. In: Zachos, F.; Habel, J. (Eds.). Biodiversity hotspots. Berlin: Springer Berlin Heidelberg, 2011. p.3-22. https://doi.org/10.1007/978-3642-20992-5_1.

Moldenke, A. R. Arthropods. In: Weaver, R.W.; Angle, J.S.; Bottomley, P.S. (Eds.). Methods of soil analysis. Part 2 - microbiological and biochemical properties. Madison: SSSA, 1994. p. 517-542. (SSSA Book Serie, 5).

Nunes, L. A. P. L.; Araújo, A. S. F.; Pessoa, M. M. C.; Sousa, R. S.; Silva, J. D. C.; Matos-Filho, C. H. A. Edaphic fauna in a vegetation gradient in the Sete Cidades National Park. Brazilian Journal of Biology, v. 79, n. 1, p. 45-51, 1 jan. 2019. https://doi.org/10.1590/1519-6984.174135

Nunes, L. A. P. L.; Silva, D. I. B. da; Araújo, A. S. F. de; Leite, L. F. C.; Correia, M. E. F. Characterization of edaphic fauna in management systems for forage production in the State of Piauí. Revista Ciência Agronômica, v. 43, n. 1, p. 30-37, 2012. https://doi.org/10.1590/ S1806-66902012000100004

Oliveira Filho, L. C. I.; Baretta, D. Por que devemos nos importar com os colêmbolos edáficos? Revista Scientia Agraria, v. 17, n. 2, p. 21-40, 2016. https://doi.org/10.5380/rsa.v12i2.48242.

Oliveira, M. P. A.; Bastos-Pereira, R.; Torres, S. H. S.; Pereira, T. S.; Batista, F. M.; Alves, J. P.; Iniesta, L. F. M.; Bouzan, R. S.; ChagasJr, A.; Prous, X.; Pietrobon, T.; Ferreira, R. L. Choosing sampling methods for Chilopoda, Diplopoda and Isopoda (Oniscidea): A case study for ferruginous landscapes in Brazilian Amazonia. Applied Soil Ecology, v. 143, p. 181-191, 2019. https://doi.org/10.1016/j. apsoil.2019.07.012. 
Pompermaier, V. T.; Kisaka, T. B.; Ribeiro, J. F.; Nardoto, G. B. Impact of exotic pastures on epigeic arthropod diversity and contribution of native and exotic plant sources to their diet in the central Brazilian savanna. Pedobiologia, v. 78, p. 150607, 2020. https:// doi.org/10.1016/j.pedobi.2019.150607

R Core Team. No TitleR: A language and environment for statistical computing. https://www.r-project.org. 22 Jun. 2020.

Santos, D. P.; Santos, G. G.; Santos, I. L. dos; Schossler, T. R.; Niva, C. C.; Marchão, R. L. Caracterização da macrofauna edáfica em sistemas de produção de grãos no Sudoeste do Piauí. Pesquisa Agropecuaria Brasileira, v. 51, n. 9, p. 1466-1475, 2016. https:// doi.org/10.1590/S0100-204X2016000900045.

Santos, G. G.; Silveira, P. M.; Marchão, R. L.; Becquer, T.; Balbino, L. C. Macrofauna edáfica associada a plantas de cobertura em plantio direto em um Latossolo Vermelho do Cerrado. Pesquisa Agropecuária Brasileira, v.43, n.1, p.115-122, 2008. https://doi. org/10.1590/S0100-204X2008000100015,

Sauvadet, M.; Chauvat, M.; Brunet, N.; Bertrand, I. Can changes in litter quality drive soil fauna structure and functions? Soil Biology and Biochemistry, v. 107, p. 94-103, 2017. http://dx.doi. org/10.1016/j.soilbio.2016.12.018

Sousa, D.M.G.; Lobato, E. Cerrado: Correção do solo e adubação. Planaltina: Embrapa Cerrados, 2004. 416p.
Tan, B.; Yin, R.; Yang, W.; Zhang, J.; Xu, Z.; Liu, Y.; He, S.; Zhou, W.; Zhang, L.; Li, H.; Wang, L.; Liu, S.; You, C. Soil fauna show different degradation patterns of lignin and cellulose along an elevational gradient. Applied Soil Ecology, v. 155, e103673, 2020. https://doi.org/10.1016/j. apsoil.2020.103673.

Torres, J. L. R.; Pereira, M. G.; Rodrigues Junior, D. J.; Loss, A. Production, decomposition of residues and yield of maize and soybeans grown on cover crops. Revista Ciência Agronômica, v. 46, n. 3, p. 460-468, 2015. https://doi.org/10.5935/1806-6690.20150026.

Varjão, S. L. De S.; Benati, K. R.; Peres, M. C. L. Efeitos da variação temporal na estrutura da serrapilheira sobre a abundância de aranhas (Arachnida: Araneae) num fragmento de Mata Atlântica (Salvador, Bahia). Revista Biociências, v. 16, n. 1, 2010. http://periodicos.unitau. br/ojs/index.php/biociencias/article/view/1104/780. 22 Jun. 2020.

Vasconcelos, W. L. F. de; Rodrigues, D. de M.; Silva, R. O. C.; Alfaia, S. S. Diversity and abundance of soil macrofauna in three land use systems in Eastern Amazonia. Revista Brasileira de Ciência do Solo, v. 44, e0190136, 2020. https://doi.org/10.36783/18069657rbcs20190136.

Wall, A. M.; Campbell, D. I.; Morcom, C. P.; Mudge, P. L.; Schipper, L. A. Quantifying carbon losses from periodic maize silage cropping of permanent temperate pastures. Agriculture, Ecosystems and Environment, v. 301, e107048, 2020. https://doi.org/10.1016/j. agee.2020.107048. 